\title{
Abundance of ants (Hymenoptera: Formicidae) and the functional groups in two different habitats
}

\author{
ANANTO TRIYOGO ${ }^{1, \bullet}$, BUDIADI $^{1}$, S.M. WIDYASTUTI ${ }^{1}$, SENA ADI SUBRATA $^{2}$, SUWITO SETYO BUDI $^{3}$ \\ ${ }^{1}$ Department of Silviculture, Faculty of Forestry, Universitas Gadjah Mada. Jl. Agro No. 1, Bulaksumur, Sleman 55281, Yogyakarta, Indonesia. \\ Tel./fax.: +62-274-512102, "email: triyogo99@yahoo.com. \\ ${ }^{2}$ Department of Forest Resource Conservation, Faculty of Forestry, Universitas Gadjah Mada. Jl. Agro No. 1, Bulaksumur, Sleman 55281, Yogyakarta, \\ Indonesia \\ ${ }^{3}$ Program of Forest Management, Vocational School, Universitas Gadjah Mada. Jl. Jacaranda Sekip II, Sleman 55281, Yogyakarta, Indonesia
}

Manuscript received: 10 December 2019. Revision accepted: 19 April 2020.

\begin{abstract}
Triyogo A, Budiadi, Widyastuti SM, Subrata SA, Budi SS. 2020. Abundance of ants (Hymenoptera: Formicidae) and the functional groups in two different habitats. Biodiversitas 21: 2079-2087. Land development often affects the quantity and diversity of ants (Hymenoptera: Formicidae). The aim of this study, therefore, was to determine and compare the ant species abundance and the functional groups between two different habitats, representing land development, including pioneer and agroforestry. This research involved a survey of the ants at the Forest Research Education (FRE) of Wanagama I Yogyakarta, and data were accumulated over a period of five months (April, May, June, July, and August). In addition, pit-fall trap and direct collection methods were used, involving the placement of 54 pit-fall traps at two habitats, and the ant specimens were retrieved after a two day period. The results show the total individual abundance of 2,310 and 2,067, on agroforestry and pioneer, respectively. Furthermore, the species richness and diversity index was higher in agroforestry $(7 ; 2.01)$, compared with pioneer $(6 ; 1.49)$, where the three dominant species include, Anoplolepis gracilipes, Solenopsis sp., Odontoponera denticulata; and Anoplolepis gracilipes, Odontoponera denticulata, Camponotus sp., respectively. Conversely, the highest amount of invasive ants (Solenopsis sp.) was observed in agroforestry, which negatively impacted on the presence of native species (Odontoponera denticulata). In addition, PCA analysis showed the development of three ant groups on each habitat, hence agroforestry made more real differences in the aspect of species abundance, and none in terms of richness. Therefore, notable differences were observed in the ant communities between both habitats, and agroforestry was indicated as a disturbed area, based on the increment in tramp and invasive ants, alongside low abundance of native and functional groups.
\end{abstract}

Keywords: Agroforestry, ant diversity, functional group, pioneer habitat

\section{INTRODUCTION}

The process of land development or succession is generally followed by changes in the community structure over a certain period of time (Buma et al. 2017), aimed at restoring the ecosystem through species diversity and by the formation of new compositions. This progression is terminated after attaining balanced landscape conditions in the ecosystem, and restoring the damages made to the community. Furthermore, successions have traditionally been categorized as primary, which occurs in areas with no previous support for living organisms, or secondary, as seen in degraded forest regions, resulting from disturbances in remnant vegetation.

The habitat where succession occurs provides important information on vegetation or fauna diversity, and possible interactions between biotic and abiotic components (Mace et al. 2012). This process possibly occurs through (1) natural regeneration, or (2) accelerated by human intervention (Horn 1975), which specifically requires management decisions, during the selection of plant or site (Zhu 2005). This includes the practice of revegetation, and other forms of land use, including agroforestry practice (Triyogo et al. 2019). Furthermore, agroforestry practices are considered suitable for both ecological and economic benefits (van Noordwijk et al. 2012), due to the tendency to reduce risks associated with land damage (Jiang et al. 2017), ability to prevent damages from pests (Pumarino et al. 2015), and increase the farmers' income (Salazar-Diaz and Tixier 2019).

Previous studies on the impacts of land-use system, including agroforestry, and the relationship with arthropod diversity have been conducted (Triyogo et al. 2019), although researches to specifically examine the level of species response to variations in habitat types are limited. Moreover, numerous questions related to biodiversity in different habitats have been raised, with respect to the impact of changes in the shape of ecosystems, where the community at the species level is considered capable of describing the processes and functions (Gray et al. 2018) using ants as indicators (Folgarait 1998; Hashimoto \& Mohamed 2010; Woodcock 2011). This approach is adopted because of the abundance (Schultz 2000) and voracity (Folgarait 1998) of this species, which poses important ecological functions (Del Toro et al. 2012; Meyer et al. 2013), and is also known to exhibit complex interactions during ecological condition assessment programs (Majer and Nichols 1998; Wang et al. 2001; Pecarevic et al. 2010). 
Holldöbler and Wilson (1990) stated that ants indicate a healthy ecosystem, while the number of species significantly correlates with the faunal characteristics of soil (number of orders and richness) (Touyama et al. 2002). These are biological markers used to evaluate environmental changes, due to the ease of collection, the dominant characteristic biomass, advanced taxonomy, and sensitivity to environmental changes (Agosti and Alonso 2000; Shahabudin 2011). Furthermore, other studies on red-wood ant (Formica lugubris) provide an overview of the composition and concentration of heavy metals (Skaldina et al. 2018), despite the limitations experienced while specifically assessing of insect response on a specieslevel. These consequently raise questions connected with the possibility of differences in ant community structure between natural and agroforestry habitat, and the probability of being affected by changes in land development.

The Forest Research Education (FRE) of Wanagama I focus on the creation of suitable study materials related to the biophysical, hydrological and socio-economic success of succession processes, forest rehabilitation, and critical areas. These forest areas comprises of several compartments assumed to describe the process of land development, including the conditions of pioneers or agroforestry. However, studies on changes in the structure of ants community following various land developments at FRE has never been conducted, hence this investigation compares the communities in two different types of habitat assumed to represent possible variations in land development. Furthermore, the information about ant functional groups present in the studied areas are expected to serve as bioindicators of the current condition. The objectives of this research, therefore, were to compare (i) the diversity of ants in different habitats, (ii) the species composition as well as community structure, and (iii) the functional groups on ants.

\section{MATERIALS AND METHODS}

\section{Study area}

This study was performed in FRE of Wanagama 1, Gunung Kidul District, Yogyakarta Province, approximately $35 \mathrm{~km}$ south-east of Yogyakarta city, Indonesia. The research focus was on two different habitats representing land development, including: (i) pioneer, observed in compartment 6 (S 07 ${ }^{\circ} 54.276^{\prime}$-E $110^{\circ} 31.518^{\prime}$ ). This region was mostly occupied by gamal tree (Gliricidia sepium), with the stand age of approximately more than 20 years, at the time of this investigation. (ii) Agroforestry area, conducted in compartment 17 (S 07054.236'-E $\left.110^{\circ} 31.917^{\prime}\right)$. In addition, the distance recorded between both habitats was about $3 \mathrm{~km}$ (Figure 1).

The difference between these two habitats was marked by the vegetation component and human interventions (Table 1). Therefore, data on insect and environment were collected in April, May, June, July, and August 2018.

\section{Ant collection and identification procedure}

Ants were surveyed during a five-month period (April to August 2018). Table 2 shows the measurement of various parameters, which were recorded alongside, including air temperature of each plot, obtained with a temperature probe (Baldr Digital Thermometer), light intensity, determined using a digital lux meter (DX-100 Takemura Electric Works Ltd.), and also percentage humidity.

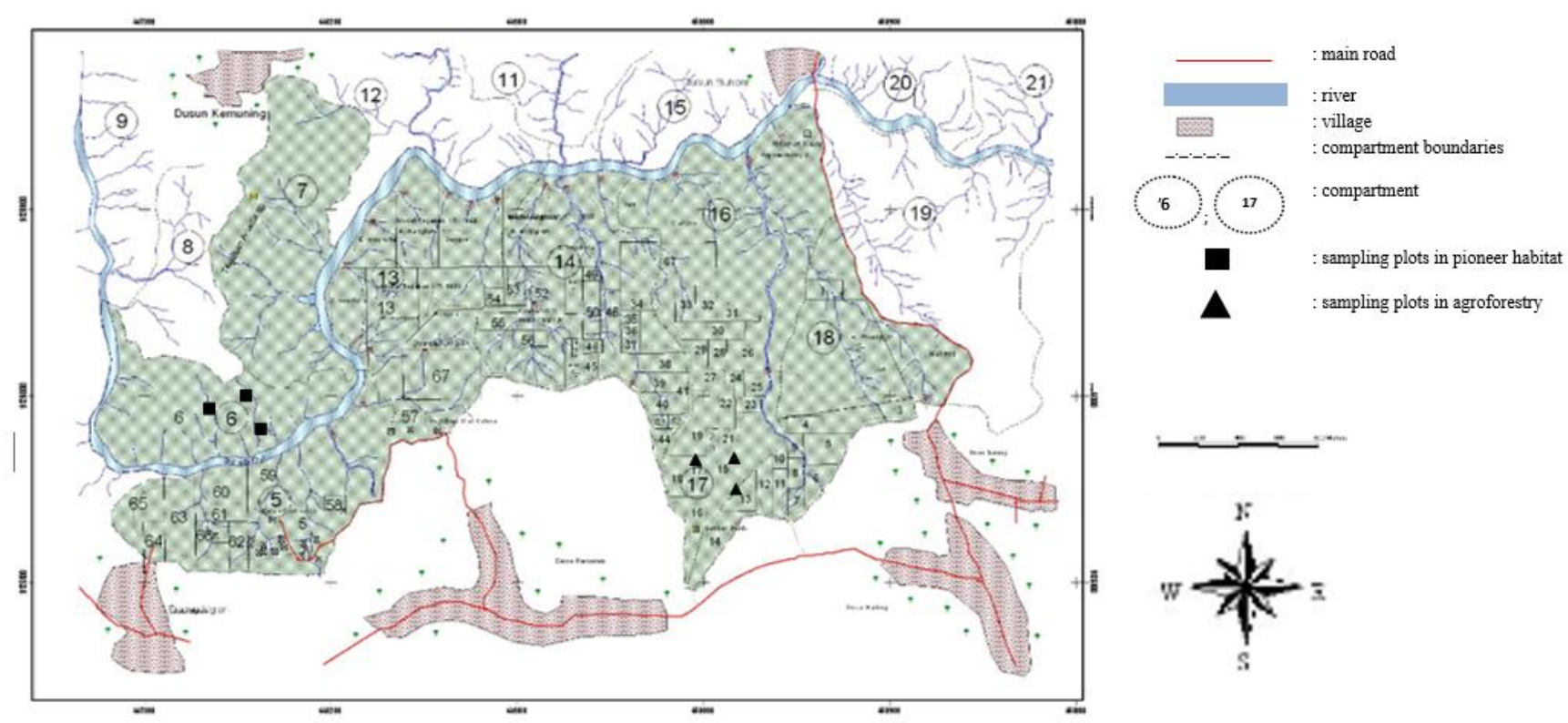

Figure 1. Map of the FRE Wanagama I. The spatial arrangement of the plots used on each habitat, pioneer (compartment 6) and agroforestry (compartment 17) was indicated by square and triangle form, respectively 
Table 1. Description on each habitat, agroforestry and pioneer, was based on vegetation growth during the five observation months and data related to soil condition

\begin{tabular}{|c|c|c|}
\hline \multirow[t]{2}{*}{ Month- } & \multicolumn{2}{|c|}{ Plant composition } \\
\hline & Agroforestry & Pioneer \\
\hline April & $\begin{array}{l}\text { Trees (Eucalyptus sp.); Old perennial tropical grass } \\
\text { (Pennisetum purpureum); weeds (Ageratum conyzoides); } \\
\text { Legume (Groundnut Arachis villosulicarpa); Banana } \\
\text { (Musa sp.); Empon-empon (Traditional medicinal } \\
\text { plants); and Herbs. }\end{array}$ & $\begin{array}{l}\text { Pioneer tree species }(G \text {. sepium); shrubs (Caesalpinia } \\
\text { sappan and Eupatorium odoratum) }\end{array}$ \\
\hline May & $\begin{array}{l}\text { Trees (Eucalyptus sp.); Banana (Musa sp.); Empon- } \\
\text { empon (Traditional Medicinal plants). }\end{array}$ & \\
\hline June & $\begin{array}{l}\text { Trees (Eucalyptus sp.); Cassava (Manihot utilisima); } \\
\text { Banana (Musa sp.). }\end{array}$ & \\
\hline July & $\begin{array}{l}\text { Trees (Eucalyptus sp.); Young perennial tropical grass } \\
\text { (Pennisetum purpureum); Cassava (Manihot utilisima); } \\
\text { Banana (Musa sp.); and Herbs. }\end{array}$ & \\
\hline August & $\begin{array}{l}\text { Trees (Eucalyptus sp.); Young perennial tropical grass } \\
\text { (Pennisetum purpureum); Cassava (Manihot utilisima); } \\
\text { Banana (Musa sp.); Empon-empon (Traditional } \\
\text { Medicinal plants); and Herbs. }\end{array}$ & \\
\hline Description & $\begin{array}{l}\text { In this present study, practice of agroforestry was in early } \\
\text { level (Triyogo et al. 2017). This area has Alfisols soil } \\
\text { (clay fraction is dominated by kaolinite) and deeper (up } \\
\text { to } 90 \mathrm{~cm} \text { ) soil depth (Supriyo 1992) found soil organic } \\
\text { carbon content in } 0-10 \mathrm{~cm} \text { layer under various forest } \\
\text { stands to vary from } 1.3 \text { to } 2.8 \% \text {, with soil depth can be } \\
110 \mathrm{~cm} \text { deep (Supriyo et al. } 2013 \text {; Supriyo 1992). }\end{array}$ & $\begin{array}{l}\text { Prior to rehabilitation, the area was characterized by } \\
\text { scarce and scattered soil patches between rocks. There } \\
\text { were no human activities on this site. Plant pioneer } \\
\text { species } G \text {. sepium dominated with various ages with } \\
\text { dense crown density. Supriyo ( } 2004) \text { classified the soil } \\
\text { that developed in these areas as Entisols (Lithosol) on } \\
\text { the basis that it has shallow soil depth }(<20 \mathrm{~cm}) \text {. }\end{array}$ \\
\hline
\end{tabular}

Table 2. Environment condition on each habitat, agroforestry and pioneer, were observed on April to August 2018

\begin{tabular}{|c|c|c|c|c|c|c|}
\hline \multirow[b]{2}{*}{ Month } & \multicolumn{3}{|c|}{ Agroforestry } & \multicolumn{3}{|c|}{ Pioneer } \\
\hline & $\begin{array}{c}\text { Temperature } \\
\left({ }^{\circ} \mathrm{C}\right)\end{array}$ & $\begin{array}{c}\text { Humidity } \\
(\%)\end{array}$ & $\begin{array}{c}\text { Light intensity } \\
\text { (Lux) }\end{array}$ & $\begin{array}{c}\text { Temperature } \\
\left({ }^{\circ} \mathrm{C}\right)\end{array}$ & $\begin{array}{c}\text { Humidity } \\
(\%)\end{array}$ & $\begin{array}{c}\text { Light intensity } \\
\text { (Lux) }\end{array}$ \\
\hline \multirow[t]{3}{*}{ April } & 31.3 & 77 & 8270.9 & 32 & 77 & 8087.6 \\
\hline & 31 & 75.7 & 9570 & 32.5 & 75.7 & 8186 \\
\hline & 31.6 & 78 & 8796.5 & 31 & 78 & 8056.7 \\
\hline \multirow[t]{3}{*}{ May } & 32.9 & 73 & 7146.6 & 32 & 73 & 8298 \\
\hline & 33 & 72.3 & 7021.6 & 32.5 & 72.3 & 8278 \\
\hline & 32.8 & 73 & 7156 & 32 & 73 & 8196.7 \\
\hline \multirow[t]{3}{*}{ June } & 32 & 65 & 7625 & 35 & 68.5 & 7233 \\
\hline & 34.45 & 64.8 & 7565 & 32.4 & 67 & 7014.7 \\
\hline & 34.15 & 65 & 7840 & 32.3 & 67.6 & 6729 \\
\hline \multirow[t]{3}{*}{ July } & 33.7 & 69 & 12840 & 32.2 & 67.5 & 9600 \\
\hline & 32 & 69 & 11450 & 31 & 74 & 9689.7 \\
\hline & 32 & 71 & 12057 & 31.5 & 75 & 9674 \\
\hline \multirow[t]{3}{*}{ August } & 41.6 & 43 & 14500 & 36.7 & 67 & 10900 \\
\hline & 42.8 & 44.5 & 14489 & 38 & 68.7 & 9889.7 \\
\hline & 42.9 & 43 & 14340 & 40 & 66 & 9736.9 \\
\hline
\end{tabular}

A total of 6 sampling plots, measuring $20 \times 20 \mathrm{~m}^{2}$ were randomly placed on the habitats, with pioneer and agroforestry consisting of 3 each. Also, 9 pitfall traps were placed in the center of the individual plot, by using a grid method (Triyogo et al. 2017; 2019), hence a total of 108 were set up at each observation time. Therefore, the ant collection process was performed two times in a month (once per two weeks), summing up to 10 observations during the five-month period. The pitfall trap was a plastic container measuring $45 \mathrm{~mm}$ in diameter and $55 \mathrm{~mm}$ deep, which was half-filled with $50 \%$ ethylene solution, and buried with the rim flush to the ground surface at each point (Ribeiro et al. 2011). In addition, an inverted petridish was positioned directly above each trap to avoid filling by rainfall, without impeding the access by ants.

Furthermore, the ants were counted in digital photographs of ceramic plates, and the collected insects are brought to the laboratory for identification up to the species level. In addition, specimen observation was conducted using the stereomicroscope (SCW PG Carton Optical Industries), while taxonomic keys were used for species identification (Bolton 1994; McArthur 2007; Heterick 2009; Terayama 2009), and through online ant databases (Antweb.org, Antbase.net) Therefore, classification was 
performed based on the five functional groups, including: (i) Generalized Myrmicinae (GM): Crematogaster sp.; (ii) Opportunist (OPP): (A. gracilipes, Tetramorium sp., $P$. megacephala); (iii) Cryptic species (CS): Pyramica sp., Solenopsis sp.; (iv) Subordinate Camponotini (SC): Camponotus sp.; and (v) Specialist Predator (SP); $O$. denticulata (Andersen 1995, 1997).

\section{Data analysis}

The number of genus, subfamily and species obtained from the two habitats was counted for each observation month. Subsequently, the total abundance of individual ant per species was pooled based on habitat, and the relative abundance (number of individual per ant species per trap) was also calculated. In addition, species richness, Diversity (H`) (Krebs (2009) and Evenness index’s (J') (Pielou 1969) were measured, and Morisita`s similarity index (Morisita 1959) was used to make a comparison between the ant communities of both areas under investigation.

The abundance of individual ants was pooled for each habitat, on the basis of functional groups (Andersen 1995, 1997). The data obtained was adopted in the exploration of community structure, using the principal coordinates analysis (PCA), while vector overlays were applied to visualize the species correlated with the first two axes. In addition, vector calculation was performed based on the correlation between each species' abundance and the first two PCA axes, and is known to indicate the strength and sign of the relationship between each species and the PCA axes. However, only vectors measuring a length of at least 0.5 were included, and $X^{2}$ test was used to compare the difference in functional structure (a total of species and individuals) between two habitats on a $5 \times 2$ contingency table. Statistical analyses were performed using SPSS version 22.0.

\section{RESULTS AND DISCUSSION}

\section{Diversity of ants}

Table 3 shows a total of 4,373 ants, belonging to eight species and three subfamilies, recorded during the fivemonth observation period (April-August).

The total abundance of each species varied between the study locations (Figure 2.A), and with the exception of $P$. megacephala, Solenopsis sp., and Pyramica sp., the others were identified in both agroforestry and pioneer. Meanwhile, observation in terms of relative abundance showed variations between both habitats (Figure 2.B), with $A$. gracilipes being comparably higher, and $O$. denticulata lower on agroforestry. In addition, Solenopsis sp. was not present in the pioneer area, while Pyramica sp. was recognized in low abundance, and absent on agroforestry.

Our results demonstrate a comparably higher total abundance of ant species on agroforestry habitat, characterized by species richness and diversity (Table 4). However, the result shows similarity in terms of ant community between both sample locations (Table 4).

The results of eigenvalues for the three axes of Principal Component Analysis (PCA) regarding the abundance of eight species were $2.96,1.77$, and 1.40 on agroforestry, which provided $87.3 \%$ explanation for variance, in the aspect of species abundance. Meanwhile, the values reported for pioneer were 2.62, 1.67, and 1.07, explaining $89.4 \%$ of the variance. Figures 3.A and 3.B showed differences in the community structures, while PCA for the abundance of ant species in paired agroforestry (Figure 3.A) and pioneer (Figure 3.B) indicated a strong tendency for three groups on each habitat type.

Each functional group showed different changes in terms of richness and abundance, particularly in the lower units of pioneer habitat, with the exception of GM, while OPP demonstrated the least value (Figures 4.A and 4.B). Based on these conditions, a comparison of the five groups showed no significant difference between habitat type $\left(X^{2}\right.$ test, $\mathrm{df}=3, p>0.05)$, although the parameter of functional composition obtained using abundance was significantly different $(p<0.01)$. Therefore, GM and CS were identified to be higher on agroforestry, while OPP, SP, and SC were more superior in pioneer.

Table 4. Species richness, Diversity ( $\left.\mathrm{H}^{\circ}\right)$, Evenness (E`), and Similarity index among ant communities at two different habitats

\begin{tabular}{lcccc}
\hline $\begin{array}{c}\text { Type of } \\
\text { habitat }\end{array}$ & $\begin{array}{c}\text { Species } \\
\text { richness }\end{array}$ & $\begin{array}{c}\text { Diversity } \\
\left(\mathbf{H}^{\prime}\right)\end{array}$ & $\begin{array}{c}\text { Evenness } \\
\left(\mathbf{E}^{\prime}\right)\end{array}$ & Similarity \\
\hline Agroforestry & 7 & 2.01 & 0.28 & 0.83 \\
Pioneer & 6 & 1.49 & 0.30 & \\
\hline
\end{tabular}

Table 3. The presence of ant on subfamily and species level on two different habitats during five observation month

\begin{tabular}{|c|c|c|c|c|c|c|c|c|c|c|c|}
\hline \multirow{2}{*}{ Subfamily } & \multirow{2}{*}{ Species } & \multicolumn{5}{|c|}{ Agroforestry } & \multicolumn{5}{|c|}{ Pioneer } \\
\hline & & April & May & June & July & August & April & May & June & July & August \\
\hline Formicinae & Anoplolepis gracilipes & + & + & + & + & + & + & + & + & + & + \\
\hline Formicinae & Camponotus sp. & & & & & + & & & & + & + \\
\hline Ponerinae & Odontoponera denticulata & + & + & + & + & + & + & + & + & + & + \\
\hline Myrmicinae & Crematogaster sp. & + & + & + & + & + & & & + & & + \\
\hline Myrmicinae & Tetramorium sp. & & + & & & & & & & + & + \\
\hline Myrmicinae & Pheidole megacephala & & + & & & & & & & & \\
\hline Myrmicinae & Solenopsis sp. & & & & + & + & & & & & \\
\hline
\end{tabular}

Note: "+"= present 


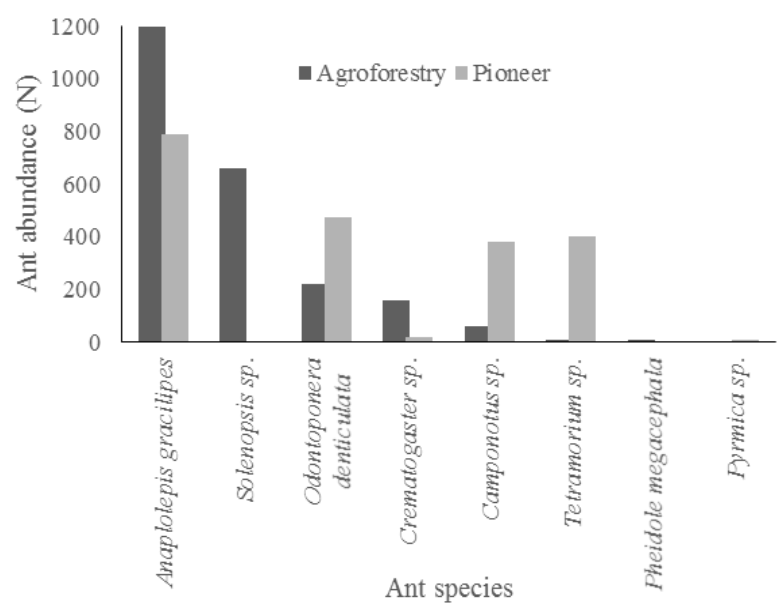

A

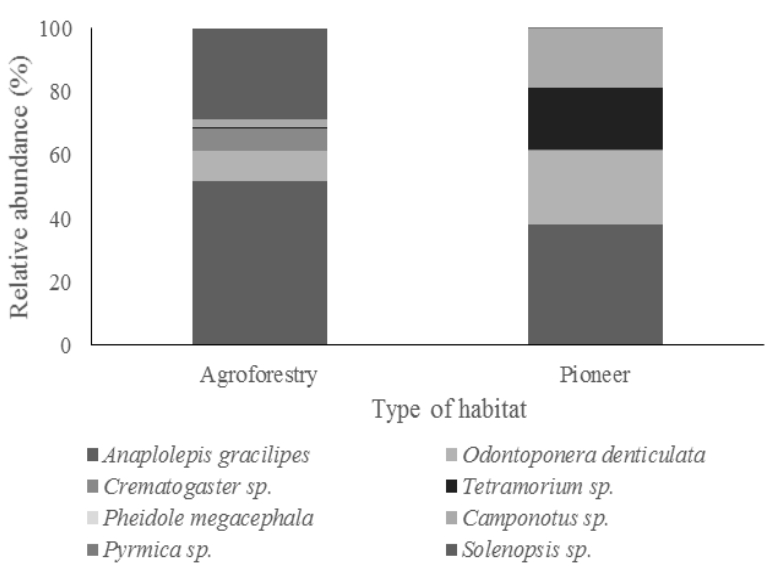

B

Figure 2. Observation of ant species at two different types of habitats. A. The total abundance of ant species, and b. Percentage of ant species

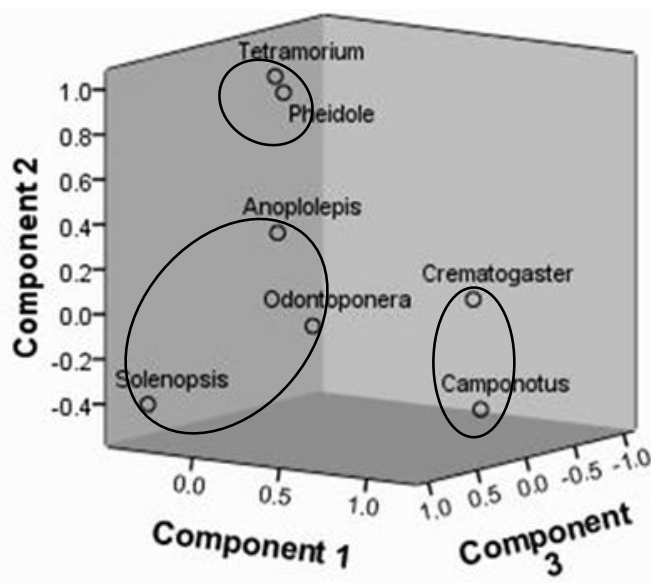

A

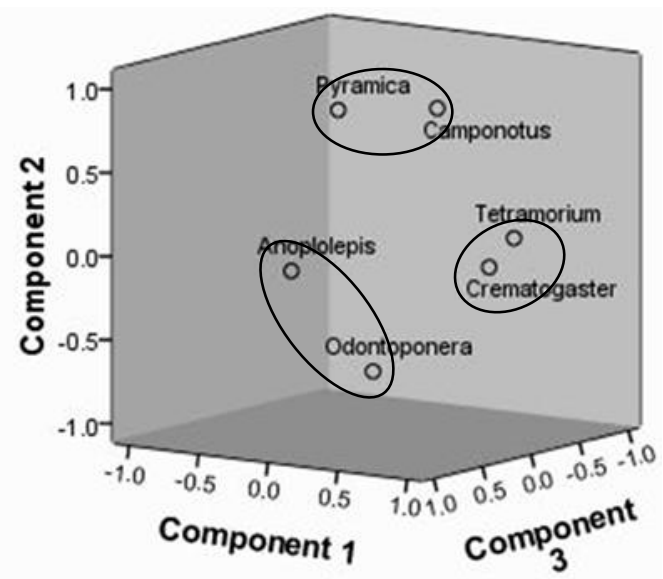

B

Figure 3. Principal component analysis of community structure based on abundance data on two types of habitats: A. Agroforestry, B. Pioneer land

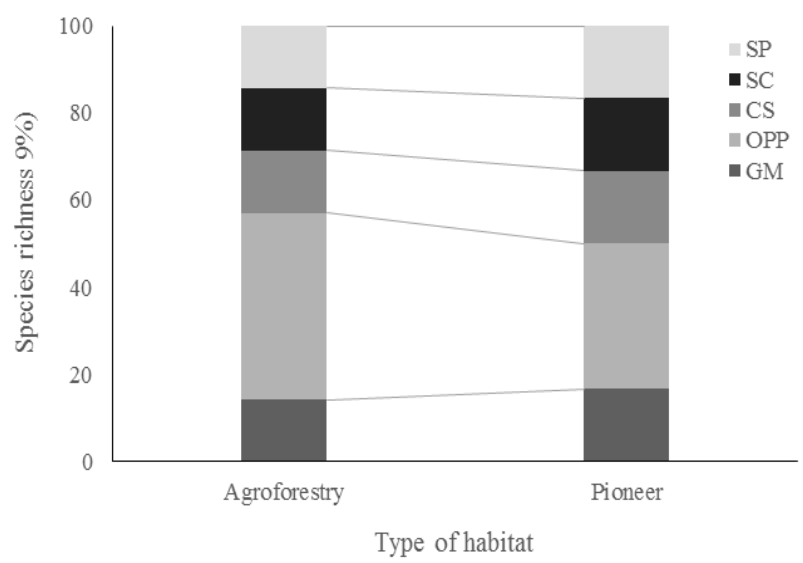

A

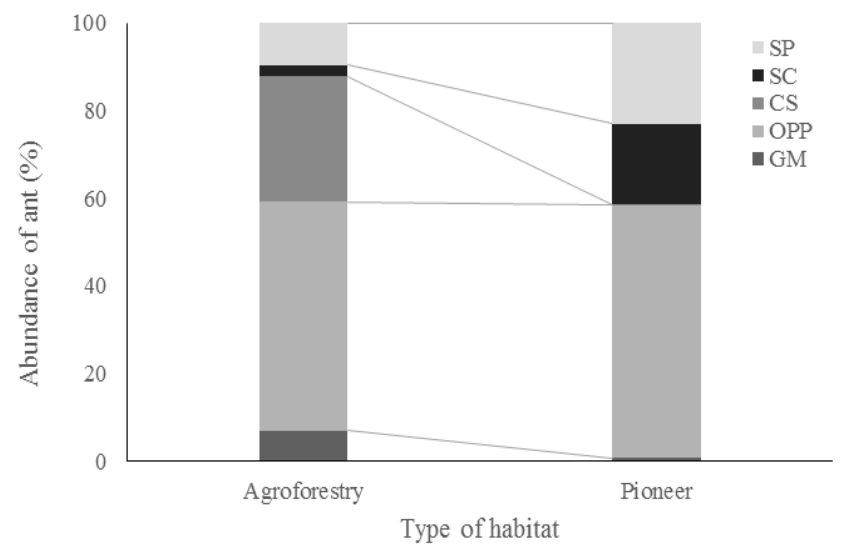

B

Figure 4. Composition of species richness (A) and abundance (B) in five functional groups. Functional groups were defined as follows (Andersen 1995, 1997): GM, Generalized Myrmicinae (Crematogaster sp.); OPP: Opportunist (Anoplolepis gracilipes, Tetramorium sp., Pheidole megacephala); CS: Cryptic species (Pyramica sp., Solenopsis sp.); SC: Subordinate Camponotini (Camponotus sp.); SP: Specialist Predator (Odontoponera denticulata). Different letters above the bar indicate significant difference in different habitats 


\section{Discussion}

Diversity of ants

The presence of ants has been highlighted a major bioindicator in ecosystems (Diamé et al. 2018; Andersen 2018). However, relatively few studies have examined the possible differential abundance, based on functional groups on different used lands or habitats. This study aimed at identifying the differences in patterns between the richness, abundance, and functional groups of ant species identified in agroforestry and pioneer habitats. The results showed a higher abundance in the agroforestry, which is a human landscape modified by integrating woody vegetation (trees or shrubs) with crops and animal production systems (Mosquera-Losada et al. 2009; Torralba et al. 2016). This system consequently increases the biodiversity and ecosystem services (Torralba et al. 2016), and plant diversity was observed to be a stronger predictor of ant diversity ( $\mathrm{Li}$ et al. 2017). Conversely, pioneer habitat represented the former condition of FRE Wanagama I as a critical land, which is dominated by soil and rocks, covered by the dominant species of G. sepium and understories. In addition, the directional modification in plant communities observed at a certain time (from the pioneer to the next level of succession), was generally followed by a change in the extent of interaction between plants and consumers (phytophagous insect) (Brown 1984), while the value for abundance correlates with the above-ground vegetation as a food resource, and also as a protectant against phytophagous organisms (Rubiana et al. 2015).

This study results show the inability for differences in plant structure and composition to vary the dominant ant species between the locations under investigation. In addition, $A$. gracilipes was identified as the most abundant in both, followed by Solenopsis sp. (identified in only agroforestry), Crematogaster sp. (abundant in agroforestry), $O$. denticulata, Camponotus sp. and Tetramorium sp. (abundant in pioneer), while $P$. megacephala and Pyramica sp occurred in low amounts in the two habitats.

Anoplolepis gracilipes is a yellow crazy ant with strong invasive characteristics, which originates from Asian regions and is known to exhibit pest behaviors (Wetterer 2005; Drescher et al. 2007; Tschinkel and King 2017). This present study shows thes dominance of this species in both habitats. In addition, A. gracilipes has previously been documented as a useful indicator, due to the fast spreading accompanying changes in habitat, alongside the intirinsic ability to influence native species (Gillespie and Reimer 1993; Sinu et al. 2017). Previous study have also reported this species as behaviorally dominant in terms of speedy discovery and monopolization of food baits, compared with the native ants (Drescher et al. 2011), Furthermore, they are capability of building supercolonies (Stewart et al. 2014; Sinu et al. 2017), indicating the ability to affect the indigenous fauna and biotic interactions on a novel habitat. The study outcome supports previous reports stipulating an association between the ant and land-use systems with the characteristic features of low tree canopy cover (Bos et al. 2008), identified in the agroforestry area. However, the dominance of $A$. gracilipes in both investigated locations indirectly shows the potential capacity to monopolize numerous living resources.

The results also demonstrate the positive impact of agroforestry on the abundance of Solenopsis sp., which was not feasible in the pioneer, while $P$. megacephala was recognized as a low abundant species in agroforestry. Previous study demonstrated how the positive effects of plant diversification in agroecosystems cause an upsurge in the prevalence of a predator (Dassou and Tixier 2016), while some other researches established a strong association between the genus Solenopsis populations and human-altered habitats (Zettler et al. 2004), as seen in agroforestry. Hence, these systems and other anthropological activities are expected to have an indirect positive impact in terms of abundance, into becoming a cosmopolitan tramp species (Tschinkel 2006; Ascunce et al. 2011).

The abundance of the native ant $O$. denticulate was comparably higher on the pioneer area. Previous study reported on the possibility for the genus Odontoponera to prefer inhibiting specific regions (Yamane 2009; Terayama 2009), as seen in the features of the pioneer land observed in this study. Therefore, the lower abundance in agroforestry was attributed to the pressure of three aggressive and invasive species, including the dominant Solenopsis sp., and A. gracilipes, alongside $P$. megacephala which was low in abundance. This outcome corroborates the findings that recognize the existence of invasive species as an important indicator of damaging possibilities towards the local communities (Rabitsch 2011), therefore leading to a decline in the species richness and evenness of ant community (Chan and Guenard 2019).

This study data affiliates the abundant of Crematogaster sp. in agroforestry with the presence of crops and the factor of temperature. The assumption was based on the report stipulating the genus Crematogaster as a group of nectar foraging minor pests of some plants, which exhibit greater activity in the afternoon (Sanfiorenzo et al. 2018; Patient et al. 2019). However, Crematogaster was also identified in pioneer, due to the intrinsic ability for the genus cosmopolitan to thrive in a variety of habitats, including tree canopies or on branches (Gawade and Patwardhan 2019; Radchenko and Dlussky 2019). Conversely, an observation of the Camponotus sp. showed a different pattern, with greater abundance in the pioneer area, although both Camponotus and Crematogasters form associations known as parabiosis, under similar habitats (Menzel et al. 2008; Orivel and Leroy 2011). This study result showed the respectively higher suitability in pioneer and agroforestry habitat.

\section{Community structure}

Our study shows a total of three groups of ant communities amongst the two habitats, which include firstly, Camponatus sp. and Crematogaster sp., as the generalized predators in agroforestry. This association has been identified in many parts of the world (Menzel et al. 2008), characterized by the ability to share similar foraging trails and nests, and is also known as parabiosis (Orivel and Leroy 2011). These two insects have also been affiliated 
with extrafloral nectaries (Santos and Del-Claro 2009; Sanfiorenzo 2018), and previous reports have explained the inability for parabiotic ants to prefer foraging in the understory plants or on the ground. Hence, there is a reduced tendency of widespread in the soil and vegetation (Vicente et al. 2014, 2016). As shown in the pioneer habitat, Camponotus sp. tends to be close with Pyramica sp. while Crematogaster sp. closer with Tetramorium sp .. Thus, our results indicate that the association that has existed in another habitat was able to change due to the presence of other ants species or change of habitat.

Secondly: the combination of A. gracilipes, Solenopsis $\mathrm{sp}$, and O.denticulate identified either in agroforestry, which collectively play an important role as a predator, including similarities in the characteristics of sensitivity towards habitat disturbances. Conversely, intercropping was identified as a practical way of increasing plant diversity in agroecosystems, which provides an alternative food and habitat source to arthropods, including general predators (Dassou et al. 2015; Rubiana et al. 2015), and also the studied cropping systems. This was due to the ability to contribute towards several ecosystems, including the aspect of pest regulation (Dassou et al. 2016).

Thirdly; the final group consisted of Tetramorium $\mathrm{sp}$ and $P$. megacephala was found in agroforestry habitat. Previous studies have shown the high tendency for genus Pheidole and Tetramorium of tramp species to exist in habitats with the human association (agroecosystem in this study), and also exhibit invasive characteristics (McGlynn 1999; Schultz and McGlynn 2000; Rubiana 2015).

\section{Functional groups}

Despite the species and abundance of ants, another approach towards determining the conditions of an ecosystem was by observing the variations in functional groups (Read and Anderson 2000), which cause altertions in processes and services (Gonzáles et al. 2018). In addition, ant diversity is generally known to increase alongside an elevation in land quality and plant composition (Rubiana et al. 2015; Dassau and Tixier 2016), which is consistent with the findings of this current investigation, which showed no difference in the functional group of both study locations. However, the pattern indicates greater values, based on the species richness, and also significantly higher records for GM and CS, in terms of ant abundance, in the agroforestry, compared to pioneer. This is in accordance with a previous study, which reported on the greater effect of different land quality on the structure of ant community, compared to diversity (Kwon et al. 2014).

The most common ants present in both locations were the OPP, which has previously been reported as general foragers, known to occupy waste ground or poor habitat (Andersen 1995). In addition, the subordinate, camponotini, presented with similar pattern as SP. The functional group data demonstrated a preference for SC in the pioneer lands, characterized by low plant diversity and the dominance of one plant species, subsequently leading to colonization by SP. However, low plant diversity tends to influence an increase in specialist herbivores on a smaller scale (Dassau and Tixier 2016), which consequently affects SP abundance positively.

The abundance of SC on pioneer suggests the habitat to be an undisturbed area, representing the initial condition of FRE Wanagama I as a critical location with naturally occurring succession and minimum human interventions. In addition, the dominance of $G$. sepium tree species within a wide age range results in the development of a closed canopy cover, which leads to littered forest floors. Conversely, the agroforestry is a developed form of pioneer, devoid of canopy covers. These areas are characterized by high human activities, including land management, clearing, weeding, planting, and crop plant maintenance. The appearance of GM is generally related to the level of land damage, which is apparently unaffected by use modifications (Gómez et al. 2013). This investigation demonstrated an unexpectedly abundant amount of GM in agroforestry, which presumably resulted from the lack of interaction between ant species, while group SC and SP were more in the pioneer habitat. Furthermore, several factors were assumed to influence the shape of structure and the community of ant, including interspecific relationships (Hölldobler and Wilson 1990), as well as interactions with plants, animals and fungi (Schultz and McGlynn 2000).

In conclusion, there were variations between the ant communities in natural habitat (pioneer) and those exposed to human interventions (agroforestry). Based on functional groups, significant differences were observed in terms of ant abundance, which was on the basis of species richness. Furthermore, an increment in tramp ants, alongside the low abundance of native species, and the nature of the functional groups found in agroforestry are indicative of a disturbed area. These results suggest the need to conduct proper practices, in order to provide an ecologically positive impact.

\section{ACKNOWLEDGEMENTS}

This study was supported by the National Agency for Research and Innovation ministry of Research and Technology through Grand of Fundamental Research 2018 with MoU No: 69/UN1/DITLIT/DIT-LIT/LT/2018.

\section{REFERENCES}

Agosti D, Alonso LE. 2000. The ALL Protocol. Ants: Standard Methods for Measuring and Monitoring Biodiversity. Smithsonian Institution Press. Washington DC.

Andersen AN. 1995. A classification of Australian ant communities, based on functional groups which parallel plant life-forms in relation to stress and disturbance. J Biogeogr 22: 15-29.

Andersen AN. 1997. Using ants as bioindicators: multiscale issues in ant $\begin{array}{lllll}\text { community ecology. Conserv } & \text { Ecol } 1 & 1 & \text { (1): } 8 .\end{array}$ http://www.consecol.org/vol1/iss 1/art8/

Andersen AN. 2018. Responses of ant communities to disturbance: Five principles for understanding the disturbance dynamics of a globally dominant faunal group. J Anim Ecol 88 (3): 350-362. DOI: 10.1111/1365-2656.12907. 
Ascunce MS, Yang CC, Oakey J, Calcaterra L, Wu WJ, Shih CJ, Goudet J, Ross KG,Shoemaker D. 2011. Global invasion history of the fire ant Solenopsis invicta. Science 331: 1066-1068.

Bolton B. 1994. Identification Guide to the Ant Genera of The World. Harvard University Press, Cambridge, MA.

Bos MM, Tylianakis JM, Steffan-Dewenter I, Tscharntke T. 2008. The invasive yellow crazy ant and the decline of forest ant diversity in Indonesian cacao agroforests. Biol Invasions 10: 1399-1409. DOI: $10.1007 / \mathrm{s} 10530-008-9215-4$

Brown VK. 1984. Secondary succession: insect-plant relationships. Bioscience 34 (11): 710-716.

Buma B, Bisbing S, Krapek J, Wright G. 2017. A foundation of ecology rediscovered: 100 years of succession on the William S. Cooper plots in Glacier Bay, Alaska. Ecology 98 (6): 1513-1523.

Chan KH,Guénard B. 2019. Ecological and socio-economic impacts of the red import fire ant, Solenopsis invicta (Hymenoptera: Formicidae), on urban agricultural ecosystems. Urban Ecosyst. DOI: 10.1007/s11252019-00893-3

Dassou AG, Carval D, Dépigny S, Fansi G, Tixier P. 2015. Ant abundance and cosmopolites sordidus damage in plantain fields as affected by intercropping. Biol Control 81: 51-57.

Dassou AG, Tixier P. 2016. Response of pest control by generalist predators to local-scale plant diversity: a meta-analysis. Ecol Evol 6 (4): 1143-1153.

Del Toro I, Ribbons RR, Pelini SL. 2012. The little things that run the world revisited: a review of ant-mediated ecosystem services and disservices (Hymenoptera: Formicidae). Myrmecol News 17: 133146.

Diamé L, Rey JY, Vayssières JF, Grechi I, Chailleux A, Diarra K. 2018. Ants: Major functional elements in fruit agro-ecosystems and biological control agents. Sustainability 10 (1): 23. DOI: $10.3390 / \mathrm{su} 10010023$

Drescher J, Blüthgen N, Feldhaar H. 2007. Population structure and intraspecific aggression in the invasive ant species Anoplolepis gracilipes in Malaysian Borneo. Mol Ecol 16 (7): 1453-1465.

Drescher J, Feldhaar H, Bluthgen N. 2011. Interspecific aggression and resource monopolization of the invasive ant Anoplolepis gracilipes in Malaysian Borneo. Biotropica 43:93-99.

Folgarait PJ. 1998. Ant biodiversity and its relationship to ecosystem functioning: a review. Biodivers Conserv 7 (9): 1221-1244.

Gawade A, Patwardhan AP. 2019. Height preference for nest building by Crematogaster subnuda Mayer, 1879 in Aarey Colony near Sanjay Gandhi National Park, Mumbai, Maharashtra, India. Intl J Entomol Res 4: $32-36$

Gillespie RG, Reimer N. 1993. The effect of alien predatory ant (Hymenoptera: Formicidae) on Hawaiian endemic spiders (Araneae: Tetragnathidae). Pac Sci 47 (1): 21-33.

Gómez C, Casellas D, Oliveras J, Bas JM. 2003. Structure of groundforaging ant assemblages in relation to land-use change in the northwestern Mediterranean region. Biodivers Conserv 12: 21352146.

González E, Buffa L, Defagó MT, Molina SI, Salvo A, Valladares G. 2018. Something is lost and something is gained: loss and replacement of species and functional groups in ant communities at fragmented forests. Landsc Ecol 33 (12): 2089-2102.

Gray RE, Ewers RM, Boyle MJ, Chung AY, Gill RJ. 2018. Effect of tropical forest disturbance on the competitive interactions within a diverse ant community. Sci Rep 8 (1): 5131.

Hashimoto Y, Mohamed M. 2010. Ground-dwelling ant diversity in Maliau Basin, Borneo: Evaluation of hand-sorting methods to estimate ant diversity. Tropics 19 (2): 85-92.

Heterick BE. 2009. A Guide to The Ants of South-Western Australia Western Australian Museum, Perth, Australia

Hölldobler B, Wilson EO. 1990. The Ants. Harvard University Press, Cambridge, MA

Horn HS. 1975. Forest succession. Sci Am 232 (5): 90-101.

Jiang XJ, Liu W, Wu J, Wang P, Liu C, Yuan ZQ. 2017. Land degradation controlled and mitigated by rubber based Agroforestry systems through optimizing soil physical conditions and water supply mechanisms: A case study in Xishuangbanna, China. Land Degrad Dev 28 (7): 2277-2289.

Krebs CJ. 2009. Ecology: The Experimental Analysis of Distribution and Abundance. 6th ed. Pearson Benjamin Cummings, San Fransisco, CA.
Kwon TS, Lee CM, Sung JH. 2014. Diversity decrease of ant (Formicidae, Hymenoptera) after a forest disturbance: different responses among functional guilds. Zool Stud 53 (1): 37.

Li Q, Hoffmann BD, Lu ZX, Chen YQ. 2017. Ants show that the conservation potential of afforestation efforts in Chinese valley-type savanna is dependent upon the afforestation method. J Insect Conserv 21 (4): 621-631. DOI: 10.1007/s10841-017-0005-0.

Mace GM, Norris K, Fitter AH. 2012. Biodiversity and ecosystem services: a multilayered relationship. Trends Ecol Evol 27 (1): 19-26. DOI: 10.1016/j.tree.2011.08.006.

Majer JD, Nichols OG. 1998 Long-term recolonization patterns of ants in Western Australian rehabilitated bauxite mines with reference to their use as indicators of restoration success. J Appl Ecol 35 (1): 161-182.

McArthur AJ. 2007. A key to Camponotus Mayr of Australia, pp. 290351. In: Snelling RR, Fisher BL, Ward PS (eds) Advances in Ant Systematics (Hymenoptera: Formicidae): Homage to EO. Wilson-50 years of contributions. Memoirs of the American Entomological Institute, 80. American Entomological Institute, Ann Arbor, MI.

McGlynn TP, 1999. The worldwide transfer of ants: Geographichal distribution and ecological invasions. J Biogeogr 26 (3): 535-548.

Menzel F, Blüthgen N, Schmitt T. 2008. Tropical parabiotic ants: highly unusual cuticular substances and low interspecific discrimination. Front Zool 5 (1): 16

Meyer ST, Neubauer M, Sayer EJ, Leal IR, Tabarelli M, Wirth R. 2013. Leaf-cutting ants as ecosystem engineers: topsoil and litter perturbations around Atta cephalotes nests reduce nutrient availability. Ecol Entomol 38 (5): 497-504. DOI: 10.1111/een.12043

Morisita M. 1959. Measuring of the dispersion of individuals and analysis of the distributional patterns. Mem Fac Sci Kyushu Univ Ser E2 (21): $5-23$.

Mosquera-Losada MR, McAdam JH, Romero-Franco R, SantiagoFreijanes JJ, Rigueiro-Rodróguez A. 2009. Definitions and components of agroforestry practices in Europe. Agrofor Eur. Springer, Dordrecht

Orivel J, Leroy C. 2011. The diversity and ecology of ant gardens (Hymenoptera: Formicidae, Spermatophyta: Angiospermae). Myrmecol News 14: 73-85.

Patient DF, Nchiwan NE, Koehler H. 2019. Abundance and diversity of insect pests on maize, cowpea and okra in a comparative experiment testing effects of intercropping and insecticide in the Cameroonian Guinean savannah and Sudano Sahelian agro-ecological zones. J Exp Agric Intl 29 (6): 1-20.

Pecarevic M, Danoff-Burg J, Dun RR. 2010. Biodiversity on broadwayenigmatic diversity of the societies of ants (Formicidae) on the streets of New York City. Plos One 5 (10): e13222. DOI: 10.1371/journal.pone.0013222

Pielou EC.1969. An Introduction to Mathematical Ecology. WileyInterscience, New York, USA

Pumarino L, Sileshi GW, Bripenberg S, Kaartinen R, Barrios E, Muchane MN, Midega C, Jonsson M. 2015. Effects of agroforestry on pest, disease and weed control: a meta-analysis. Basic Appl Ecol 16 (7): 573-582. DOI: 10.1016/j.baae.2015.08.006

Rabitsch W. 2011. The hitchhiker's guide to alien ant invasions. BioControl 56 (4): 551-572.

Radchenko A, Dlussky GM. 2019, June. First record of the ant genus Crematogaster (Hymenoptera: Formicidae) from the Late Eocene European ambers. Ann Zool 69 (2): 417-421.

Read JL, Andersen AN. 2000. The value of ant's as early warning bioindicators: responses to pulsed cattle grazing at an Australian arid zone locality, J Arid Environ 45: 231-251.

Ribeiro-Júnior MA, Rossi RV, Miranda CL, Ávila-Pires TC. 2011. Influence of pitfall trap size and design on herpetofauna and small mammal studies in a Neotropical Forest. Zoologia 28 (1): 80-91.

Rubiana R, Rizali A, Denmead LH, Alamsari W, Hidayat P, Pudjianto,Hindayana D, Clough Y, Tscharntke T, Buchori D. 2015. Agricultural land use alters species composition but not species richness of ant communities. Asian Myrmecol 7: 73-85.

Salazar-Díaz R, Tixier P. 2019. Effect of plant diversity on income generated by agroforestry systems in Talamanca, Costa Rica. Agrofor Syst 93 (2): 571-580.

Sanfiorenzo A, Sanfiorenzo M, Vargas R, WaitsL, Finegan B. 2018. Potential pollinators of understory populations of Symphonia globulifera in the Neotropics. J Pollination Ecol 22 (1): 1-10.

Santos JC, Del-Claro K. 2009. Ecology and behaviour of the weaver ant Camponotus (Myrmobrachys) senex. J Nat Hist 43 (23-24): 14231435 . 
Schultz TR, McGlynn TP. 2000. The interactions of ants with other organisms. In: Agosti D, Majer JD, Alonso LE, Schultz TR (eds) Ants: Standard Methods for Measuring and Monitoring Biodiversity. Smithsonian Institution Press. Washington DC

Schultz TR. 2000. In search of ant ancestors. Proc Natl Acad Sci USA 97 14028-14029.

Shahabudin. 2011. Effect of land use change on ecosystem function of dung beetles: Experimental evidence from Wallacea Region in Sulawesi, Indonesia. Biodiversitas 12 (3): 177-181.

Sinu PA, Sibisha VC, Reshmi MN, ReshmiKS, Jasna TV, Aswathi K, Megha PP. 2017. Invasive ant (Anoplolepis gracilipes) disrupts pollination in pumpkin. Biol Invasions 19 (9): 2599-2607.

Skaldina O, Peräniemi S, Sorvari J. 2018. Ants and their nests as indicators for industrial heavy metal contamination. Environ Pollut 240: 574-581.

Stewart PLC, Richards G, Wickenden ABJ. 2014. The control of yellow crazy ants (Anoplolepis gracilipes). An Empirical Study. Intl J Eco Dev 27 (1): 56-63.

Supriyo H, Matsue N, Yoshinaga N. 1992. Chemistry and mineralogy of some soils from Indonesia. Soil Sci Plant Nutr 38: 217-225.

Supriyo H, Prehaten D, Figyantika A. 2013. Soil properties of eight fores stands resulted from rehabilitation of degraded land on the tropica area for almost ahalf century. Jurnal Manusia dan Lingkungan 20 294-302. [Indonesian]

Supriyo H. 2004. Perkembangan fisik. In: Pramudibyo RIS, Suseno OH, Supriyo H, Soekotjo, Naiem M, Iskandar U. Dari bukit-bukit gundul sampai ke Wanagama-1. Yayasan Sarana Wana Jaya, Yogyakarta. [Indonesian]

Terayama, MAMO. 2009. A synopsis of the family Formicidae of Taiwan (Insecta: Hymenoptera). Res Bull Kanto Gakuen Univ. Lib Arts 17: 81-266.

Torralba M, Fagerholm N, Burgess PJ, Moreno G, Plieninger T. 2016. Do European agroforestry systems enhance biodiversity and ecosystem services? A meta-analysis. Agric Ecosyst Environ 230: 150-161.

Touyama Y, Yamamoto T, Nakagoshi N. 2002. Are Ants Useful Bioindicator?: the Relationship between Ant Species Richness and Soil Macrofaunal Richness, in Hiroshima Prefecture. Edaphologia 70 33-36.

Triyogo A, Suryanto P, Widyastuti SM, Baresi AD, Zughro IF. 2017. Kemelimpahan dan struktur tingkat trofik serangga pada tingkat perkembangan agroforestri jati yang berbeda di Nglanggeran, Gunung Kidul Yogyakarta. Jurnal Ilmu Kehutanan 11 (2): 239-248. [Indonesian]

Triyogo A, Widyastuti SM, Budiadi, Budi SS, Varanita S. 2019. The diversity of ants in different land develompental: An agroforestry phase approach. Jurnal Ilmu Kehutanan 13. 161-170. [Indonesian]

Tschinkel WR, King JR. 2017. Ant community and habitat limit colony establishment by the fire ant, Solenopsis invicta. Funct Ecol 31 (4): 955-964.

Tschinkel WR. 2006. The Fire Ants. Belknap/Harvard University Press, Cambridge, MA

Van Noordwijk M, Tata HL, Xu J, Dewi S, Minang PA. 2012. Segregate or Integrate for Multi-Functionality and Sustained Change through Rubber-Based Agroforestry-The Future of Global Land Use. Springer. Dordrecht.

Vicente RE, Dáttilo W, Izzo TJ. 2014. Differential recruitment of Camponotus femoratus (Fabricius) ants in response to ant garden herbivory. Neotrop Entomol 43: 519-525. DOI: 10.1007/s13744-0140245-6

Vicente RE, PradoLP, Izzo TJ. 2016. Amazon rainforest ant-fauna of Parque Estadual do Cristalino: Understory and Ground-Dwelling Ants. Sociobiology 63: 894-908. DOI: 10.13102/sociobiology.v63i3.1043

Wang C, Strazanac JS, Butler L. 2001. Association between ants (Hymenoptera: Formicidae) and habitat characteristics in oakdominated mixed forests. Environ Entomol 30 (5): 842-848.

Wetterer JK. 2005. Worldwide distribution and potential spread of the long-leggedd ant, Anoplolepis gracilipes (Hymenoptera: Formicidae). Sociobiology 45: 1-21.

Woodcock P, Edwards DP, Fayle TM, Newton RJ, Khen CV, Bottrell SH, Hamer KC. 2011. The conservation value of South East Asia's highly degraded forests: evidence from leaf-litter ants. Philosophical Trans R Soc London B Biol Sci 366 (1582): 3256-3264.

Yamane S. 2009. Odontoponera denticulata (F. Smith) (Formicidae: Ponerinae), a distinct species inhabiting disturbed areas. Ari 32: 1-8.

Zettler JA, Taylor MD, Allen CR, Spira TP. 2004. Consequences of forest clear-cuts for native and nonindigenous ants (Hymenoptera: Formicidae). Ann Entomol Soc Am 97: 513-518.

Zhu W. 2005. Consideration of soil ecological processes in restoration and succession. Acta Phytoecol Sin 29 (3): 479-486. 